\title{
THE STATUS OF INTERNATIONAL AGREEMENTS CONCLUDED BY THE EUROPEAN UNION IN THE EU LEGAL ORDER**
}

Summary: $\quad$ The European Union is a member of the international community and is a party to numerous international agreements. The status of these international agreements in the EU legal order however is not made expressly clear by the Treaties. The most pertinent question that arises is whether secondary EU law may be reviewed in the light of international agreements in annulment procedures or preliminary ruling procedures before the Court of Justice of the EU. In its jurisprudence the Court of Justice has tied the possibility of review to the question of the direct effect of international treaties, but there are some issues of consistency in this regard. This problem is a part of the broader question of the relationship of international law and EU law, including the question whether this relationship is more akin to a monist or a dualist approach.

Keywords: $\quad$ International agreements of the European Union, EU law, International law, direct effect, judicial review, Court of Justice of the European Union

The European Court of Justice has been analysing the status of international agreements concluded by the European Union in the EU legal order for decades. The Union, as an entity with an autonomous legal order separate from international law is itself a subject of international law. The relationship between domestic law and international law is an evergreen issue of classical international law, and logically this question has arisen with regard to the relationship between international law and the law of the European Union as well. The complexity of the situation is increased by the fact that these international agreements become part of European Union law, thus they are binding on the Member States of the Union via EU law as well. The most important problems of interpretation concerning the Union's international agreements are, on the one hand, the question of direct effect, and on the other hand, the question of where international agreements of the Union are to be placed in the hierarchy of EU law, and to what extent they serve as a standard of review of secondary EU law.

\footnotetext{
Ágoston Mohay, PhD, Assistant Professor, Department of International and European Law, Faculty of Law, University of Pécs, H-7622 Pécs, 48-as tér1, Hungary. Email address: mohay.agoston@ajk.pte.hu. ORCID: http://orcid.org/0000-0002-1166-2400.

** This paper was supported by the János Bolyai Research Scholarship of the Hungarian Academy of Sciences.
} 


\section{THE CONCLUSION OF INTERNATIONAL AGREEMENTS BY THE EUROPEAN UNION}

The European Union has an independent international legal personality (Article $47 \mathrm{TEU}){ }^{1}$ it is involved in international relations, and may carry rights and obligations under the rules of public international law. The EU concludes international agreements with third States and other international organizations, via a process regulated by the TFEU. Its legal personality is - similarly to that of international organizations - derivative and limited. The Union may conclude agreements with one or several third State(s) or international organization(s) in the following cases:

a) where the Treaties so provide, or

b) where the conclusion of an agreement is necessary in order to achieve, within the framework of the Union's policies, one of the objectives referred to in the Treaties,

c) where the conclusion of an agreement is provided for in a legally binding Union act, or,

d) where the conclusion of an agreement is likely to affect common rules or alter their scope [Article 216 (1) TFEU].

The Union's competence to conclude international agreements is exclusive when its conclusion is provided for in a legislative act of the Union or is necessary to enable the Union to exercise its internal competence, or in so far as its conclusion may affect common rules or alter their scope of application [Article 3 Section 2 TFEU].

In some cases, primary law specifically provides for the EU's competence to conclude international agreements - such as in the field of Neighbourhood Policy [Article 8 (2) TEU], Common Foreign and Security Policy (Article 37 TEU), or regarding the accession of new Member States (Article 49 TEU). In addition, the Union may conclude with one or more third states or international organisations association agreements establishing reciprocal rights and obligations, common action and special procedure (Article 217 TFEU).

The procedure to be followed in concluding the Union's international agreements is regulated by Article 218 TFEU in detail; the Council is entitled to conclude agreements, in principle acting by a qualified majority, ${ }^{2}$ in several specified cases - such as association agreements - subject to obtaining the consent of the European Parliament, and in other cases after obtaining

1 Prior to the Treaty of Lisbon, the European Community (formerly: the European Economic Community) had legal status under international law, whereas the European Union did not - until 1 December 2009. Thanks to the Treaty of Lisbon, the EU has been endowed with international legal personality and has replaced the EC (as its legal successor) - cf. Articles 1 and 47 TEU. Jacobs argues that, although the international personality had already been accepted in the case of the EC, having regard, inter alia, to the judgment of the Court of Justice in the ERTA case, there are arguments that the article on the legal personality of the Community would have been inherently relevant for national law; and it did not explicitly refer to international legal personality (as opposed to the relevant Article of the ECSC Treaty). Jacobs, F. G., Direct effect and interpretation of international agreements in the recent case law of the European Court of Justice, in: Dashwood, A.; Maresceau, M., Law and Practice of EU External Relations. Salient Features of a Changing Landscape, Cambridge, 2008, p. 13.

2 By way of derogation from the general rule, the Council shall act unanimously when the agreement concerns an area where the unanimity is required for the adoption of Union acts, as well as for association agreements and agreements to be concluded with candidate countries under Article 212. The Council also decides unanimously on the agreement to accede to the European Convention on Human Rights (and the decision to conclude the agreement will only come into force after the Member States have approved them in accordance with their constitutional requirements) - see Article 218 (8) TFEU. 
the Parliament's opinion. An important competence of the European Court of Justice in this regard is that it can a priori examine the question of compatibility: any Member State, the European Parliament, the Council or the Commission may seek the opinion of the Court of Justice on the compatibility of a proposed international agreement with the Treaties. If the Court gives an unfavourable opinion, the envisaged agreement may only enter into force if it is amended or the Treaties themselves are revised [Article 218 (11) TFEU]. ${ }^{3}$

In addition, the European Union concludes certain international agreements in a way that not only the Union but the Member States, too, act as contracting parties (mixed agreements). Written primary law does not specifically provide for mixed agreements, neither before the Treaty of Lisbon nor in the current version. These agreements fall within areas where the competences of the EU and the Member States are closely interlinked - see for example the UN Convention on the Law of the Sea ${ }^{4}$, the WTO Agreement ${ }^{5}$ or the Aarhus Convention. ${ }^{6}$ Concerning mixed agreements, the institutions of the Member States and the Union are to cooperate closely in the implementation of the commitments. ${ }^{7}$ The obligation of close cooperation also includes that a Member State is obliged to inform or consult with "competent [EU] institutions before initiating a dispute settlement procedure under a mixed agreement". ${ }^{8}$

\section{THE NATURE OF INTERNATIONAL AGREEMENTS CONCLUDED BY THE EUROPEAN UNION}

Agreements concluded by the Union are binding on the institutions and Member States of the Union [Article 216 (2)], namely in accordance with the principle of moving treaty borders, these treaties are binding on the States who are members of the Union at a given time. ${ }^{9}$ The binding nature of these agreements follows for the EU as subject of international law from the principle of pacta sunt servanda of international law. This issue is not an unimportant one, given that the EU is party to approximately a thousand international agreements, ${ }^{10}$ a significant part of which are mixed agreements. Agreements that are binding on the Union include international agreements where the Union itself is not a contracting party, but the Union has taken over the competence(s) relating to the subject-matter of the agreement from the Member Sta-

3 A recent negative example can be seen in the Court's Opinion 2/13 (18 December 2014), by which the European Court of Justice ruled that the agreement on the European Union's accession to the European Convention on Human Rights is incompatible with EU primary law. For an analysis of the opinion see Mohay Á., Back to the Drawing Board? Opinion 2/13 of the Court of Justice on the Accession of the EU to the ECHR. Pécs Journal of International and European Law, vol. 2, no. 1, 2015, p. 28-36.

4 Case C-459/03 Commission v Ireland [2006] ECR I-04635, para 176

5 Decision 94/800/EC concerning the conclusion on behalf of the European Community, as regards matters within its competence [OJ 1994 L 336].

6 See Decision 2005/370/EC on the conclusion, on behalf of the European Community, of the Convention on access to information, public participation in decision-making and access to justice in environmental matters [OJ 2005 L 124].

7 Joined Cases C-300/98 and C-392/98 Dior and Others [ECR 2000, I-11307].

8 The judgment of the Court in the MOX case was based on this. Case C-459/03 Commission v Ireland, cited above, para. 180.

9 Schwarze, J. (Hrsg.), EU-Kommentar (3. Auflage). Nomos, Baden-Baden 2012, p. 1996.

10 Eckes, C., International law as law of the EU: The role of the Court of Justice. CLEER Working Papers 2010/6, p. 10. URL= http:// www.asser.nl/upload/documents/1212010-60145clee10-6web.pdf (Accessed 10. 5. 2014). 
tes. ${ }^{11}$ With regard to the institutions of the Union, this mandatory obligation is primarily relevant for the institutions involved in legislation to adopt (or modify or repeal) appropriate EU legal acts within their sphere of competence. ${ }^{12}$ "Pure" (i.e. non-mixed) agreements concluded by the Union become an integral part of the law of the Member States by virtue of EU law due to the special characteristics of EU law, in particular the principle of primacy of application, without the need for a separate national incorporating act..$^{13}$ In the case of mixed agreements, the situation is more complicated as these agreements are binding on Member States partly via EU law, ("reinforced" by the primacy of application), but also as 'traditional' international treaties - in line with the distribution of competences between the EU and the Member States. ${ }^{14}$ As for mixed agreements, the question arises as to whether their interpretation falls under the jurisdiction of the European Court of Justice. According to its jurisprudence, the Court of Justice has jurisdiction to interpret mixed agreements and to determine which obligations arising from such an agreement are the responsibility of the EU and which concern only the Member States. ${ }^{15}$ A fresh example highlighting the complex issues of interpretation surrounding mixed agreements is the Court of Justice's opinion (issued pursuant to Article 218 (11) TFEU, on request by the European Commission) on the Free Trade Agreement between the European Union and the Republic of Singapore, according to which the agreement cannot be concluded by the EU alone, as specifically the provisions of the agreement concerning non-direct foreign investment and those relating to dispute settlement between investors and States do not fall within the exclusive competence of the EU, and thus cannot be the subject of an agreement without the participation of the Member States. ${ }^{16}$

The European Court of Justice has already stated at an early stage in the history of integration that the agreements concluded by the Union constitute an "integral part of EU law"

11 See: Blutman, L., Az Európai Unió joga a gyakorlatban, HVG-ORAC, 2013, p. 247-248. The Court will, on a case-by-case basis, examine in detail whether the Community /Union has taken over the competences from the Member States in the context of an international agreement. This is not necessarily the case even if there is an EU act intended to incorporate certain provisions of an international agreement concluded by the Member States into EU law - see, to that effect, Case C-308/06 Intertanko et al v Secretary of State for Transport [2008] ECR I-04057, concerning the Marpol Convention on the Prevention of Pollution from Ships (1973).

12 Martines, F., Direct Effect of International Agreements of the European Union, European Journal of International Law, vol. 25, no. 1, 2014, p. 132.

13 Martines: ibid. p. 133.

14 Examining the specificities of mixed agreements is a challenging research subject in its own right, see e.g. Koutrakos, P.; Hillion, C. (eds.), Mixed agreements revisited: the EU and its Member States in the world, Oxford, 2010, p. 396.

15 Case C-240/09 Lesoochranárske zoskupenie VLK v Ministerstvo životného prostredia Slovenskej republiky [2011] ECR I-01255, para. 31. The judgment has been criticized due to the fact that the Court established its competence to interpret the provisions of the Aarhus Convention by stating that even though it was a specific matter which the Union had not yet regulated under the Convention, that provision "may fall within the scope of EU law if it relates to a field covered in large measure by it" - the European Court of Justice had established this in the case at hand, although the European Union (then still the Community) claimed in its statement of competence to the Aarhus Convention that the Member States were responsible for the implementation of Article 9 (3) of the Convention (which was at issue in the main proceedings) as long as the Union has not adopted secondary legal acts regulating the fulfilment of those obligations. Also, Regulation 1367/2006/EC [OJ 2006 L 264] which was already in force at the time of the legal dispute only contained rules relevant for the institutions and bodies of the Union (see paragraphs 32 to 43 of the judgement). For analysis and criticism see e.g. Klamert, M., Dark Matter - Competence, Jurisdiction and "the Area Largely Covered by EU Law": Comment on Lesoochranárske, European Law Review 2012, p. 340-350 and Ruffer, E., Interpretation, Implementation and Enforcement of Association Agreements: Institutional Structures, Dispute Settlement Mechanisms and the Jurisdiction of the Court of Justice of the EU, in: Šišková, N., From Eastern Partnership to the Association. A Legal and Political Analysis, Cambridge Scholars Publishing, 2014, p. 56.

16 Opinion 2/15 on the Free Trade Agreement between the European Union and the Republic of Singapore (16 May 2017) [EU:C:2017:376]. 
from the moment of their entry into force, ${ }^{17}$ the TFEU (and formerly the ECT), as we have seen, proclaim these agreements to be binding on the institutions and the Member States of the Union. Thus it can be concluded that EU law applies an automatic incorporation to such agreements. ${ }^{18}$ This can be interpreted so that the Union considers international agreements concluded by itself in a monist approach: these agreements have legal effects in the EU legal order even then if there is no legal act for their implementation. ${ }^{19}$ Concerning the agreements concluded by the Union, the two most important questions are (1) where these treaties are located in the Union's hierarchy of sources of law, and (2) whether these agreements may have direct effect - incidentally, these two features are in fact linked in the case law of the Court of Justice, but their relationship is not entirely unequivocal.

\subsection{THE DIRECT EFFECT OF INTERNATIONAL AGREEMENTS CONCLUDED BY THE UNION}

The general condition of direct effect under EU law according to settled case law is that the provision in question shall be unconditional, its application shall not depend on further action by the EU or Member State institutions and it shall be sufficiently precise (clear and precise). ${ }^{20}$ The question whether international agreements of the EU may directly confer rights and obligations on individuals which they may rely on before national courts and authorities had to be determined separately by the Court, as with other sources of EU law. According to the Court of Justice, the contracting parties are first and foremost free to choose the legal instruments necessary to achieve the purposes of the agreement. If the international agreement itself does regulate this question, the parties must comply. In all other cases however, the parties are free to decide on this matter - including the situation where the court of a contracting party (in this case the EU) declares certain provisions of the agreement to have direct effect - and it does not affect the jurisdiction of the Court of Justice if the parties have set up a forum to settle disputes relating to the agreement since the Union's international agreements form an integral part of EU law as of the date of their entry into force, and the interpretation of EU law undoubtedly falls within the jurisdiction of the Court. ${ }^{21}$ When examining some of the provisions of the Turkish association agreement, the Court made it clear that the general conditions of direct effect are also strictly examined in this regard - in the case of provisions of a purely programmatic nature requiring further action by the parties, direct effect is not possible. ${ }^{22}$

17 Case 181/73 Haegeman v Belgium [ECR 1974, 449], para. 5. The judgment relied on an association agreement with Greece.

18 De Burca, G., The ECJ and the international legal order, in: De Burca, G.; Weiler, J. H. H., The Worlds of European Constitutionalism Cambridge, 2011, p. 105. Quoted concurringly by Advocate General Niilo Jääskinen in his Opinion in Joined Cases C-401/12. P and C-403/12 P. (para. 30).

19 Opinion of Advocate General Jääskinen in Joined Cases C-401/12 P and C-403/12 P, para. 32. negative obligation for the Member State(s), but the jurisprudence of the Court has abandoned this view in Case 57/65 Lütticke v Hauptzollamt Saarlouis [ECR 1966, 205].

21 Case 104/81 Hauptzollamt Mainz v Kupferberg [ECR 1982, 3641], paras. 17-21. 
The question of the existence or absence of direct effect arose quite notably in connection with the General Agreement on Tariffs and Trade (GATT) and the World Trade Organization (WTO) agreement. The GATT, which was signed in 1947, sought to encourage the stimulation of world trade through the reduction of tariffs and the application of the "most favoured nation" rule. The WTO came into being as a further developed successor to GATT, and all the representatives of the European Community and its Member States signed the Final Act on the Uruguay Round of Multilateral Trade Negotiations in Marrakesh and the World Trade Organization Convention in 1994, and the Council concluded it on behalf of the Community with regard to the matters within its competence by Decision 94/800/EC. ${ }^{23}$ The European Community as an organisation was a founding member of the WTO, while its Member States are members of the international organization as well. The WTO intends to achieve its general objectives (raising the standard of living, full employment, ensuring a large and steadily growing volume of real income and actual demand, increasing production and trade in goods and services, protecting sustainable development and the environment, and taking into account the needs of developing countries) primarily by means of multilateral and plurilateral agreements which are annexes to the WTO agreement and relate to trade in goods and services. The WTO - within its scope - is the decisive regulatory power of international trade. The European Union, which, in the meantime, has become the legal successor of the Community by the Treaty of Lisbon (see Article $1 \mathrm{TEU}$ ), is also a member of this organization, and it is the Commission that represents the EU in the General Council of the WTO (meeting in various configurations), and in several other bodies as well. In connection with the GATTWTO agreements, the question of direct effect has been a matter for the Court on a number of occasions, but its conclusion essentially was that these commercial agreements cannot be applied directly and have no direct effect, given that their rules are not unconditional and that direct applicability in the legal systems of the Member States does not follow from the spirit, the general scheme and the provisions of these treaties - in order to establish the direct effect, the provision of the relevant international agreement must be such that it confers rights on private individuals of the EU enforceable in court. ${ }^{24}$ Thus the Court, in addition to the 'classic' requirements of direct effect, takes into account the purpose, the structure, and the system of international agreements as well when determining the existence or absence of direct effect. It cannot be considered essential that the provision of the international agreement expressly provides for the conferral of rights on individuals: it is sufficient if, on examination of the above criteria, it can be established that the agreement has intended to confer rights on individuals. ${ }^{25}$

The decisions of bodies set up by international agreements of the Union - in the case referred to, the decisions of the EC-Turkey Association Council - are also part of European Union law and may even have direct effect in so far as they contain a clearly and precisely defined obligation (right) which does not depend on any subsequent legal act in respect of its perfor-

23 Decision 94/800/EC concerning the conclusion on behalf of the European Community, as regards matters within its competence [OJ 1994 L 336].

24 See in particular: Joined Cases 21/7-24/72 International Fruit Co. [ECR 1972, 1219]; Case 9/73 Schlüter [ECR 1973, 1135]; Case 266/81 SIOT [ECR 1983, 731]; Joined Cases 267/81-269/81 SPI and SAMI [ECR 1983, 801]; Case C-280/93 Germany v Council [ECR 1994, I-04973], para. 110. The Court's use of the concepts of direct applicability and direct effect is not fully consistent in practice, in some cases the Court delimits them from one another, in some cases it does not, and this can be observed in connection with international agreements as well. See, for example, Blutman, op. cit. 11, p. 377-381. 
mance or legal effects. ${ }^{26}$ In that respect, the Court considers it irrelevant whether the decisions in question are published or not. ${ }^{27}$

In some cases, in the context of the international agreements of the Union, the Court has also recognized a kind of indirect effect. According to the Court, an individual may rely on international agreements concluded by the Union which are not directly applicable, where an EU norm expressly refers to an international agreement or if the Union adopts measures for the implementation of an international agreement (or a provision of it). ${ }^{28}$ However, in the absence of direct effect, the requirement of effective legal protection (in particular, the effective protection of the rights guaranteed under EU law) requires that the court of a Member State interpret national law in a way that it complies with the provision of an international agreement concluded by the Union lacking direct effect. ${ }^{29}$ This essentially confirms the existence of a specific version of the doctrine of the obligation of harmonious interpretation ${ }^{30}$ in the relationship between the Union's international agreements and secondary law.

\subsection{THE HIERARCHICAL POSITION OF INTERNATIONAL AGREEMENTS CONCLUDED BY THE UNION}

Written primary EU law does not regulate expressis verbis the hierarchical position of the EU's international agreements within the EU legal order. However, from the provision that 'the agreements concluded by the Union are binding on the institutions and the Member States of the Union', it can be concluded that these agreements rank in the hierarchy of EU legal sources below the primary sources (both written and non-written ones), but rank above secondary sources of EU law: consequently, the EU's international agreements may not be contrary to primary law, and secondary law may not be contrary to such international agreements. The

26 Case C-192/89 Sevince v Staatssecretaris van Justitie [ECR 1990, p. I-03461], especially P. 15 and 21-22. In the case, the direct effect of the provisions contained in the Association Councils Decisions in question was not precluded by the fact that the rules at issue provided that the detailed rules for the application of the provisions in question concerning the rights conferred on Turkish workers were laid down by national legislation, since those provisions, according to the Court, "had only clarified the obligation on Member States to take administrative measures which, as the case may be, are involved in the implementation of those provisions', but did not authorize the Member States to impose conditions or to limit the application of the precisely defined and unconditional right guaranteed by the provisions of the Association Council decisions (for Turkish employees in this case) - see paragraphs 22 to 23 of the judgment.

27 Case C-192/89, para. 24: according to the Court, non-publication of the decisions may prevent their being applied to a private individual, but "a private individual is not thereby deprived of the power to invoke, in dealings with a public authority, the rights which those decisions confer on him."

28 Case 70/87 Fediol v Commission [ECR 1989, 1781], paras. 19-22. Analysed by Blutman, op. cit. 11, p. 347-348. See also Case 69/89 Nakajima v Council [ECR 1991, I-02069].

29 Case C-240/09. Lesoochranárske zoskupenie VLK kontra Ministerstvo životného prostredia Slovenskej republiky [ECR 2011, I-01255], paras. 45-50. In this case, one of the questions was the existence or absence of the direct effect of Article 9 (3) of the Aarhus Convention, where the Court of Justice defined the aim of the provision as the effective protection of the environment. In that regard, the Court of Justice had designated as a task of the (Slovak) national court to seek to interpret the procedural rules relating to the conditions necessary for the exercise of the right to national administrative or judicial remedy as far as possible in order to comply both with the aims of that provision of the Aarhus Convention and with the aim of effective judicial protection of the rights conferred by EU law, in order to allow environmental organizations to challenge in court the decisions taken during an administrative procedure that may be contrary to EU environmental law (para. 51).

30 The principle was originally developed by the Court of Justice for directives (in order to 'remedy' the lack of the horizontal direct effect of directives - it means to impose an obligation on national courts to interpret Member States' law in accordance with the directives. See further: Kecskés L., EU-jog és jogharmonizáció, HVG-ORAC, Budapest, 2009, p. 568-573. 
primacy of international agreements over secondary law has also been confirmed by the Court of Justice, which emphasized that the relevant secondary law is, as far as possible, to be interpreted in a manner consistent with international agreements concluded by the Union. ${ }^{31}$ From the general logic of the hierarchy of sources of law it would follow that the lawfulness or the validity of the secondary legal act which is contrary to an international agreement of the Union may be reviewed by the Court of Justice for this reason - in an annulment procedure (Article 263 TFEU), or in a preliminary ruling procedure concerning the validity of an EU legal act (Article 267 b) TFEU). In the annulment procedure, incompatibility with an international agreement may be surmised under the annulment ground entitled 'infringement of the Treaties or of any rule of law relating to their application'. ${ }^{22}$ However, the Court of Justice has not always acknowledged international agreements concluded by the Union as a standard of review, that is, as a basis for the judicial review of secondary Union law, and the question of review has interestingly been linked to the issue of the direct effect of international agreements in the Court's case law.

Especially in light of the International Fruit and the Dior judgements, it can be stated that an international agreement of the EU may constitute a basis of legality/validity review if the international agreement has direct effect. ${ }^{33}$ The Court of Justice therefore examines the lawfulness of secondary law on the basis of the EU's international agreements if 'neither the nature nor the broad logic of the Convention precludes this' and, if the provisions in question are, as regards their content, unconditional and sufficiently precise. ${ }^{34}$ This aspect is, however, not always so clear: in the Netherlands v Parliament and Council (Biotechnological Inventions) case the Court of Justice held that where the provisions of an agreement do not have direct effect, that is, it does not create rights that individuals can directly rely on before the courts, this circumstance does not prevent judicial review of compliance with the obligations incumbent on the EU as a party to the agreement. ${ }^{35}$ However, the judgement does not state whether this review has any further conditions beyond that the given international agreement should be binding on the Union and the Court of Justice does not explain sufficiently in detail either why it had come to a conclusion partially different from that its case law relating to the GATT and the WTO: the Court merely refers to the fact that the Convention on Biological Diversity relevant in the case is, unlike the WTO agreement, 'not strictly based on reciprocal and mutually advantageous arrangements. ${ }^{36}$ Summing up the case law, it appears that secondary EU law may be reviewed based on an international agreement binding on the Union, where the agreement has direct effect - this is absolutely true for agreements based on the principle of reciprocity and reciprocal advantages (in particular the GATT and the WTO agreements); but

31 C-61/94 Commission v Germany [ECR1996, I-3989], para. 52. This approach is similar to the "Charming Betsy" doctrine developed by the US Supreme Court, which requires an interpretation of national law in line with international law [Murray v. Schooner Charming Betsy; 6 U.S. (2 Cranch) 64 (1804)]. The parallel is noted by Jackson, J. H., Direct Effect of Treaties in the US and the EU, the Case of the WTO: Some Perceptions and Proposals, in: Arnull, A.; Eeckhout, P.; Tridimas, T., Continuity and Change in EU Law: Essays in Honour of Sir Francis Jacobs, Oxford University Press, 2007, p. 361-382, especially p. 366-368.

Türk, A., Judicial Review in EU Law, Elgar European Law Publishing, 2009, p. 127. 
(exceptionally?) it is possible that the secondary law will be reviewed by the Court of Justice on the basis of an international agreement which is neither based on reciprocity and mutuality, yet nor does it demonstrate direct effect. ${ }^{37}$

From this point of view, however, a recent judgement delivered in the $\mathrm{Z}$ case is noteworthy: the Court of Justice has ruled that Directive 2000/78/EC establishing a general framework for equal treatment in employment and occupation cannot be examined under the UN Convention on the Rights of Persons with Disabilities (New York, 2006 ${ }^{38}$; hereinafter: CRPD), as its provisions are "programmatic", they are not sufficiently precise and unconditional. ${ }^{39}$ (The CRPD was approved by the Union in 2010; making it the first international human rights treaty to which the EU had become a contracting party..$^{40}$ ) The Court based its reasoning on the fact that it follows from (certain) provisions of the Convention that it is the task of the contracting parties, inter alia, to take all appropriate legislative, administrative, and other measures to implement the rights contained in the CRPD, thus the obligations contained in the Convention are addressed to the contracting parties and not to individuals. ${ }^{41}$ However, Article 5 (1) and (2) of the Convention contain general anti-discrimination provisions, and the recognition of their direct effect in light of the jurisprudence of the Court of Justice would not have been surprising. ${ }^{42}$ In addition, it would be difficult to conclude that the CRPD is based on reciprocity and the principle of mutual benefit, but this time the Court of Justice did not follow the line of reasoning demonstrated in the Biotechnological Inventions case.

Approaching the question of the hierarchy from the other way around is a simpler issue: the Union's international agreements cannot be contradictory to primary EU law, this is also indicated by the Court's ex ante competence concerning the compatibility of international agreements with primary law. It has been a question for decades whether the Union can accede to the European Convention on Human Rights, and if yes under what conditions: the answer to the first question is, since the Treaty of Lisbon, unequivocal in light of Article 6 (2) TEU. ${ }^{43}$ However, the accession agreement was considered by the European Court of Justice as incompatible with EU law in its opinion of December 2014 and therefore the Treaty of Accession needs to be revised in accordance with the opinion of the Court of Justice. ${ }^{44}$ Nevertheless, it would be of great significance for the protection of fundamental rights if the Union were

37 Blutman, op. cit. 11, p. 348

38 For ratifications and signatures see: Https://treaties.un.org/Pages/ViewDetails.aspx?src=TREATY\&mtdsg-no=IV-15\&chapter=4\&clang=-en

39 Case C-363/12 Z v The Government Department and The Board of Management of a Community School [ECLI: EU: C: 2014: 159], notably paras. 88-90.

40 Decision 2010/48/EC on the conclusion by the European Community of the United Nations Convention on the Rights of Persons with Disabilities [OJ 2010 L 23].

41 Case C-363/12, paras. 87-88.

42 For a similar opinion see Peers, S., Surrogate Mothers' Day in the Court of Justice: Reflections on EU sex equality law, EU Law Analysis, 18 March 2014. URL=http://eulawanalysis.blogspot.hu/2014/03/surrogate-mothers-day-in-court-of.html (Accessed 1. 4. 2017) According to Article 5 (1) of the convention in question, participating States acknowledge that all persons are equal before the law and are entitled to protection and benefit under the laws without any discrimination, and under Paragraph 2 , participating States shall prohibit any discrimination on grounds of disability and shall ensure disabled persons in all respects equal and effective legal protection against discrimination.

43 However before the Treaty of Lisbon, the Court of Justice did not see the accession of the Community to the Convention possible in the absence of an appropriate competence - see Opinion 2/94 (28 March 1996). 
to subject itself to an external human rights standard independent of the Union and to the competence of the associated judicial institution. ${ }^{45}$ (As we have seen, the ECHR would no longer be the first human rights agreement to which the Union joins; and in March 2016, the Commission proposed the conclusion of a new human rights agreement, namely the Council of Europe Convention on the Prevention and Elimination of Violence against Women ${ }^{46}$ by the Union ${ }^{47}$, but the utmost importance of the ECHR is indisputable, not least because of the decisive role of the European Court of Human Rights as the guarantor of the observance of the Convention.

\section{CONCLUDING REMARKS}

The status of the EU's international agreements in the EU legal order is characterized by a duality: on the one hand, primary law regulates these agreements (as opposed to other legal sources of international law), so their situation is in principle regulated; on the other hand, deeper issues concerning their scope and hierarchical position are not settled by the Treaties. The decades-long practice of the Court of Justice, as in many other cases, seeks to fill in the gaps in written primary law: it defined the conditions for the direct effect of international agreements concluded by the Union and has placed these agreements in the Union's legal hierarchy as norms ranking between the primary and the secondary legal sources. Despite the clarity of this hierarchical position, however, the consequence of a norm conflict between international agreements and secondary sources EU law will not always be the revision of the secondary norm based on the international agreement: as we have seen, a prerequisite for a review of legality/validity is that the relevant international agreement should possess direct effect; and the scope of the exceptions to that rule (which apparently exist) is not sufficiently delimited in the relevant case law.

In general, it can be stated that the legal effects of international law in the EU legal order and the relationship between international law and EU law are complex, and in many respects unclear issues. The law of the European Union is an autonomous legal system separate from international law and the national law of the Member States. The European Court of Justice has elaborated the principles of direct effect and the primacy of EU law, which are essential elements of the functioning of this legal order concerning the relationship between EU law and the law of the Member States, thus making it clear that the relationship between these two legal systems is not governed by the traditional dualist or monist approach which are commonly relied upon when determining the relationship between international law and domestic law. However, the autonomy of the EU legal order does not only mean a self-definition vis-à-vis domestic law but also self-determination "against” international law as well. The EU legal order, which had been established by sources of international law, and in line with the

45 On the role of the ECHR in the EU legal order, see Mohay Á., Az Emberi Jogok Európai Egyezménye az EU jogrendjében, in: Lajkó D.; Varga N. (szerk.), Alapelvek és alapjogok, Szegedi Tudományegyetem Állam- és Jogtudományi Doktori Iskola, 2015, p. 327-337. 
rules of international law, is however not traditional international law but a new sui generis supranational legal order. The jurisprudence of the Court of Justice (albeit containing some ambiguities) generally emphasizes that international law is binding on the European Union: this is the case regarding the international agreements concluded by the Union (regardless of the intricacies of the issues of direct effect and the judicial review) and regarding customary international law $^{48}$ as well, whereas the rules of international ius cogens apply to all subjects of international law. ${ }^{49}$ However, in the well-known Kadi judgment, the Court did not emphasize the binding nature of international law: it annulled an EU regulation implementing a UN Security Council resolution relating to combating the financing of terrorism. ${ }^{50}$ Of course, the Court of Justice formally merely annulled an EU regulation, but in essence it considered that the Security Council was substantively inappropriate from the point of view of the protection of (EU) fundamental rights. The since then consistently followed Kadi-doctrine developed by the Court of Justice shows - instead of the former, more "inclusive" attitude which suggests a monist relationship between EU law and international law of monistic nature) - a dualist perception of the relationship between international law and EU law ${ }^{51}$, where this relationship is governed by the EU legal order itself, and international law can permeate that legal order only under the conditions set by the constitutional principles of the EU. ${ }^{52}$ In his Opinion in Kadi, Advocate General Maduro stated that it would be incorrect to assume that, if the Union is bound by a rule of international law, EU Courts must bow to that rule with complete acquiescence and apply it unconditionally in the Community legal order: obligations under international law imposed on the Union are to be respected, but the Court primarily seeks to preserve the essential public law structure ("the constitutional framework") established by written primary EU law. ${ }^{53}$

According to a recent analysis by Advocate General Jääskinen, however, the Union stands on the grounds of a monist approach concerning international law, which inter alia encompasses the automatic incorporation of the international agreements concluded by the Union - he considers that in this respect it is irrelevant that not all international agreements can be invoked against secondary EU law as "reference norms" for reviewing their legality. ${ }^{54}$ The question, however, is how the fact that the various agreements concluded by the Union can have different effects regarding the judicial review of secondary law is compatible with this

48 Case C-286/90 Anklagemyndigheden v Poulsen and Diva Navigation Corp. [ECR 1992, I-6019], para. 9: “(...) the European Community must respect international law in the exercise of its powers and that, consequently, Article 6 abovementioned must be interpreted, and its scope limited, in the light of the relevant rules of the international law of the sea." The Court's practice does not exclude the possibility of reviewing secondary EU law based on international customary law either - see Case C-162/96 Racke v Hauptzollamt Mainz [ECR 1998, I-3655], para. 51: “In those circumstances, an individual relying in legal proceedings on rights which he derives directly from an agreement with a non-member country may not be denied the possibility of challenging the validity of a regulation which, by suspending the trade concessions granted by that agreement, prevents him from relying on it, and of invoking, in order to challenge the validity of the suspending regulation, obligations deriving from rules of customary international law which govern the termination and suspension of treaty relations."

All obligations arising from international ius cogens are erga omnes obligations - see Bruhács J., Nemzetközi jog I., Dialóg-Campus, 2008, p. 216. p. 2. 
strictly monist view and the classical guiding principles of the hierarchy of sources of law? Furthermore, if the system is indeed monist, how can it be explained that primary law ranks above international law? (Unless we are talking about the - essentially superseded - version of monism represented by Hegel, Bergbohm, and Visinszkij which advocated the primacy of domestic law - but this the author does not aim to imply.) Although Jääskinen tackles (at least the first) problem in a way consistent with his line of reasoning by stating that the monist relationship is the general rule, but there are some dualist exceptions in the case of agreements which are not directly effective.

From the point of view of international law, the same expectation prevails for the Union as for States and other members of the international community: international law obligations must be executed in good faith in accordance with the pacta sunt servanda principle. ${ }^{55}$ From the point of view of the Union, the problem of the relationship between international law and EU law is not only important because under the Treaty on European Union, the EU contributes "to the strict adherence and development of international law" in its external activities, in particular to respect the principles enshrined in the Charter of the United Nations ${ }^{56}$, but also because this issue arises in areas of major importance such as the protection of human rights, the fulfilment of obligations under the UN Charter, or the position of economically significant investment protection treaties. ${ }^{57}$

\section{BIBLIOGRAPHY}

1. Bartha I., Nemzetközi szerződések mozgásban, Dialóg Campus, 2015.

2. Blutman, L., Az Európai Unió joga a gyakorlatban, HVG-ORAC, 2013.

3. De Burca, G., The European Court of Justice and the International Legal Order after Kadi, Harvard Law Journal, vol. 51, no. 1, 2010, p. 2.

4. De Burca, G.; Weiler, J. H. H., The Worlds of European Constitutionalism, Cambridge, 2011.

5. Eeckhout, P., EU External Relations Law, Oxford University Press, 2011.

6. Jackson, J. H., Direct Effect of Treaties in the US and the EU, the Case of the WTO: Some Perceptions and Proposals, in: Arnull, A.; Eeckhout, P.; Tridimas, T., Continuity and Change in EU Law: Essays in Honour of Sir Francis Jacobs, Oxford University Press, 2007, p. 361-382.

7. Jacobs, F. G., Direct effect and interpretation of international agreements in the recent case law of the European Court of Justice, in: Dashwood, A.; Maresceau, M., Law and Practice of EU External Relations. Salient Features of a Changing Landscape. Cambridge, 2008, p. 13-33.

8. Klamert, M., Dark Matter - Competence, Jurisdiction and "the Area Largely Covered by EU Law": Comment on Lesoochranárske. European Law Review 2012, p. 340-350.

9. Ruffer, E., Interpretation, Implementation and Enforcement of Association Agreements: Institutional Structures, Dispute Settlement Mechanisms and the Jurisdiction of the Court of Justice of the EU, in: Šišková, N., From Eastern Partnership to the Association. A Legal and Political Analysis, Cambridge Scholars Publishing, 2014, p. 56.

55 The execution of obligations in good faith does not only apply to international treaties, but also covers general international law. Bruhács, op. cit. 48, p. 169.

56 Article 3 (5) TEU.

57 On bilateral investment treaties see: Bartha I., Nemzetközi szerződések mozgásban. Dialóg Campus, 2015, p. 191-206. 
10. Kecskés L., EU-jog és jogharmonizáció, HVG-ORAC, Budapest, 2009.

11. Koutrakos, P.; Hillion, C. (eds.), Mixed agreements revisited: the EU and its Member States in the world, Oxford, 2010.

12. Martines, F., Direct Effect of International Agreements of the European Union, European Journal of International Law, vol. 25, no. 1, 2014, p. 129-147.

13. Mohay Á., Az Emberi Jogok Európai Egyezménye az EU jogrendjében, in: Lajkó D.; Varga N. (szerk.), Alapelvek és alapjogok, Szegedi Tudományegyetem Állam- és Jogtudományi Doktori Iskola, 2015, p. 327-337.

14. Mohay Á., Back to the Drawing Board? Opinion $2 / 13$ of the Court of Justice on the Accession of the EU to the ECHR. Pécs Journal of International and European Law, vol. 2, no. 1, 2015, p. 28-36.

15. Schwarze, J. (Hrsg.), EU-Kommentar (3. Auflage). Nomos, Baden-Baden 2012.

16. Türk, A., Judicial Review in EU Law, Elgar European Law Publishing, 2009. 


\section{STATUS MEĐUNARODNIH SPORAZUMA SKLOPLJENIH OD STRANE EUROPSKE UNIJE U PRAVNOM SUSTAVU EU-a}

\section{Sažetak}

Europska unija je članica međunarodne zajednice i stranka u brojnim međunarodnim sporazumima. Međutim, status tih međunarodnih sporazuma u pravnom poretku EU-a nije jasno utvrđen u Ugovorima EU-a. Logično pitanje koje se nameće jest može li se sekundarno pravo EU-a preispitivati u svjetlu međunarodnih sporazuma u postupcima poništenja ili postupcima prethodnog odlučivanja na Europskom sudu pravde. U svojoj je sudskoj praksi Europski sud pravde mogućnost revizije prava povezivao s pitanjem izravnog učinka međunarodnih ugovora, no u tom pogledu javlja se problem dosljednosti. Taj je problem dio širega pitanja odnosa međunarodnoga prava i prava EU-a kao i pitanja je li taj odnos više monističkog ili dualističkog karaktera.

Ključne riječi: međunarodni sporazumi Europske unije, pravo EU-a, međunarodno pravo, izravni učinak, sudska revizija, Europski sud pravde

\section{(c) (1) (s)}

This work is licensed under a Creative Commons

Attribution-NonCommercial 4.0 International License.

* Dr. sc. Ágoston Mohay, docent na Katedri međunarodnog i europskog prava, Pravni fakultet, Sveučilište u Pečuhu, H-7622 Pécs, 48-as tér1., Republika Mađarska. Adresa e-pošte: mohay.agoston@ajk.pte.hu. ORCID: http://orcid.org/0000-0002-1166-2400. 